(C) 2020 Oxford University Press. This is a pre-copyedited, author-produced version of an article accepted for publication in Migration Studies following peer review. The version of record Lindley, Anna (2020) 'What are we afraid of? Exploring risk and immigration detention.' Migration Studies is available online at: https://academic.oup.com/migration/advancearticle/doi/10.1093/migration/mnaa021/5894662 ?guestAccessKey=fdeeb34c-dc05-4327-ae67-8301d03bb0e8 and https://doi.org/10.1093/migration/mnaa021

\title{
What are we afraid of? Exploring risk and immigration detention
}

\author{
Anna Lindley ${ }^{1}$
}

Manuscript accepted by Migration Studies, 12 Jun 2020, DOI: 10.1093/migration/mnaa021

\begin{abstract}
Risk assessment is a prominent feature of managed migration regimes. How risk is conceptualised and operationalized, however, is highly contested terrain. The extent to which immigration detention represents an appropriate response to specific risks posed by people with contingent or no legal status is particularly hotly debated. In the UK, an early adopter and until recently an eager developer of detention for the purposes of removal, the policy is that immigration officers carry out individualised risk assessments on each person detained, considering removal prospects, risk of flight and offending as well as the risk of harm to the individual. Drawing on published reports, government statistics and interviews with close observers, this article explores the premises, policy, practice and outcomes of these processes. The analysis flags multiple issues, suggesting that risk evaluation in relation to immigration detention is far from a well-oiled and reliable machine, causes unnecessary human harm, operates in a way that generates unforeseen risks for wider society, and points to other logics shaping detention.
\end{abstract}

Keywords: immigration, risk, detention, removal, compliance, crime, vulnerability

\section{Introduction}

The concept of risk permeates immigration detention governance. As a UK detention officer put it, 'We are protecting the community' (Bosworth 2014: 100). Officially framed as a means of combatting anonymity and people eluding removal, detention is implicated in wider discussions about how states control who lives on a territory, mediate access to resources and jobs, and navigate risk in a mobile world. At the same time, it is clear that detention poses risks of harm to those targeted research paints a bleak picture of the impact on mental and physical health, the disruption to economic and family existence, the legacies of detention in people's lives and implications for communities (Bosworth and Turnball 2014).

The idea of risk has become a prominent feature in many aspects of contemporary governance, and is increasingly an 'organizing concept' in managed migration regimes, with both computerised algorithms and street-level bureaucrats charged with pre-empting, containing and minimising the risks

\footnotetext{
${ }^{1}$ Department of Development Studies, SOAS, University of London, United Kingdom. A.Lindley@soas.ac.uk
} 
associated with 'unwanted' migration (Andersson 2014: 67). In law, immigration detention is intended to be an administrative, non-punitive measure used as a last resort where necessary to prevent pre-expulsion flight; less formally, it is often perceived to have deterrence and other politicaleconomic functions. In the context of hot debate about the risks of unwanted migration, what risks justify deprivation of liberty, and the risks that the detention system imposes on those it targets, it is important to scrutinize how detention decisions are made and experienced.

The UK is an interesting case: an early adopter and eager developer of a relatively large immigration detention system, it purports to adopt an individualised risk-based approach to detention. The likelihood that someone will be removed and the risk that they may break immigration rules or criminal laws while awaiting removal are at the core of political efforts to justify immigration detention and the legal framework underpinning it. At the same time, the risks that detention poses individuals detained and their families represent a key safeguarding issue and an argument for changing the system. The ways that risk informs detention decisions are highly contested: the detention scholar Bosworth argues the 'organizing principle... [and] mode of governance [of UK detention centres], is not risk, but uncertainty.' (Bosworth 2014: 164, see also Griffiths 2014).

This article explores what we can learn from published analysis, government statistics and interviews with close observers about how is risk dealt with in decisions to detain and maintain detention and how these decisions are experienced. What risks does detention, officially speaking, address and avoid? What is the conception of harm involved? What kind of evidence is brought to bear and how is it assessed? How effective is detention as a response to the risks identified and does it create new risks?

The first section explores theoretical insights into risk, governance, immigration and detention, setting the stage for the empirical analysis. The second section sets out the UK detention landscape and outlines the research methods. Then attention is focused on the four specific areas of risk considered in detention decisions: removal prospects, risk of absconding, risk of offending, and risk of harm to the individual. The analysis flags several issues in each area with premises, policy, practice and outcomes. It is clear from this analysis that immigration detention decision-making is characterised by a high degree of uncertainty for people detained and their legal representatives. The analysis also highlights ways that the current system generates unforeseen risks for wider society. This lends further support to the argument that other political-economic logics contribute substantially to detention, and to the argument for change.

\section{Governing risk: the state, immigration and detention}

There are various ways of understanding risk (Sørensen 2018). Conventional conceptualisations focus on hazards to human life that are 'calculable uncertainties', i.e. we can calculate probabilities of these events occurring, and the impact on different people exposed. Whereas objectivist approaches focus on modelling and predicting risks as accurately as possible based on available information, constructivist approaches emphasise that our understanding of risk is situated: what people assess to be a hazard tells us a lot about how people see and experience the world. Moreover, people's understanding of risks 'rubs off on reality', i.e. plays a role in reproducing or changing reality (Sørensen 2018, 8). Thus, while often portrayed as a technical matter, risk assessment and response is deeply political.

Risk management became a prominent concern with the consolidation of centralised national governments. The modern state (as complexes of institutions, discourses and practices) engages in 
governmentality - regulating its population through a range of technologies of power to foster their strength and productivity (Foucault 1991). These technologies of power may include and combine coercive sovereign power associated with executive and legislative authority, disciplinary power associated with institutions regimenting people's routines and activities, and regulatory/biopower shaping people's behaviour through social and economic policies and programmes (Foucault 1991). Increasingly seen as responsible for managing threats confronting their populations, states developed a keen interest in converting uncertainties into quantifiable risks as a basis for formulating policy interventions (Beck 1992). The post-World War II period saw the introduction of health and welfare policies designed to mitigate common risks in much of the global North, and human security and social protection has become a key theme in global development debates.

However, conventional perceptions of calculability and controllability of risk have been unsettled in various ways. In the context of advanced industrialisation we now face risks arising not so much from external hazards as from human decision-making, which are increasingly complex and incalculable it is argued that we live in a 'risk society' (Beck 1992). A global neoliberal policy turn has fostered welfare cutbacks and labour precarity, cultivating objective and subjective insecurity among many populations (Waquant 2009). Within public policy, the 'New Public Management' trend had focused on the efficient targeting of lean financial and human resources to meet predefined targets, often featuring privatisation (Alpes and Spire 2014). Meanwhile, there is a growing neoconservative emphasis on immigration and crime as existential threats to society and tight control of these as a means of shoring up state legitimacy (Bigo 2002, Waquant 2009). While these developments manifest to differing degrees and in different ways around the world, the global expansion of immigration detention is emblematic (Flynn 2014).

Risk and migration have always been intertwined: 'migration is both informed by risk and uncertainty, and generates risk and uncertainty' for migrants, and different groups of people at origin and destination (Williams and Baláž 2012, 167). Once concerned to control emigration, as a result of population growth, rising urban poverty and military advances, European governments redirected their energies towards controlling immigration (Czaika et al 2018). In the last three decades, a selective, economically utilitarian 'managed migration' approach has taken hold, seeking to optimise the benefits of 'useful' (skilled/monied) migrants while stepping up border enforcement efforts to preempt, contain and banish the other, 'unwanted' migrants: '[b]orders increasingly function as selectively permeable 'filters', allowing some people through while restricting others' (Allen and Vollmer 2018: 24, Anderson 2013).

There are various ways that, risk has become an 'organizing concept' for immigration control (Andersson 2014: 67). Discourse analysis reveals that immigration policy is insistently framed using the language of 'risks' and 'threats', coalescing with and fuelling support for more stringent controls (Vollmer 2017). Key destination countries direct funding to 'sending' and 'transit' regions to preempt and contain movement by addressing drivers and policing departures (Pécoud and Geiger 2010). Immigration officers are charged with identifying people likely to contravene their visa conditions as 'immigration risks' to be denied entry (Allen and Vollmer 2018). Controls extend inwards from territorial borders with increasing checks on status and entitlements by workplaces, landlords and service providers (Yuval-Davis et al. 2019). There is trend towards 'crimmigration', i.e. criminalisation of immigration infractions and expansion of removable criminal offences (Stumpf 2006).

This is taking place in particular bureaucratic settings. The 'bureaucratic habitus' of immigration officials increasingly emphasises 'migratory risk', embedding a culture of suspicion (Alpes and Spire 
2014, Campbell 2017). Technology plays a growing role, for instance with (semi)automation of incoming passenger checks and algorithms computing people's 'proclivities and potentialities' (Amoore 2011: 24, Allen and Vollmer 2018, Hall 2014). But human decision-making is also still very prominent - with 'migratory risk' often ill-defined in legal texts, the 'street-level bureaucrats' charged with implementing immigration policy still often retain substantial discretion to interpret data and determine outcomes (Lipsky 1980, Scheel 2017). Research has studied the implications of volatile employment conditions, high workloads, decision-making short-cuts and (dis)incentives across a range of immigration bureaucracies (Allen and Vollmer 2018, Alpes and Spire 2014, Scheel 2017).

Detention is a common feature of contemporary managed migration regimes. Whereas previously administrative internment of migrants was most often used during times of war, in the last thirty years its use has been normalised and spread across the globe (Flynn 2014, Silverman and Massa 2012). There is variety in the drivers, forms and scale of detention. For instance, it is clear that some less prosperous countries have expanded detention largely in response to external pressure / incentives from more prosperous nations seeking to contain onward movement (Flynn 2014). By contrast, Mainwaring and Cook (2018) identify an assertive 'Anglo model' (Australia, US, UK and Canada): prosperous, strong states with relatively neoliberal economies, and national imaginaries riven with tension between human rights and white hegemony, in which the use of indefinite detention has also expanded significantly.

The adoption of immigration detention as part of migration management can be explained in various ways. Detention may have perceived expressive, deterrence and coercive functions: symbolically reasserting state control in the context of public anxiety, discouraging people from violating immigration laws, and encouraging them to co-operate with expulsion (Costello 2015, Flynn 2016, Leerkes and Broeders 2010). Scholars also point to a double-edged care-and-control logic whereby detention works to manage extreme social exclusion by containing 'undeportable deportable aliens' who might otherwise be street homeless, and more likely to commit crimes (Leerkes and Broeders 2010, Bosworth 2014). In some contexts the privatisation of facilities in expectation of efficiency gains, in line with new public management, creates an element of path dependency, by empowering security companies to influence detention policy and providing a mechanism for states to blame-shift (Menz 2011, Flynn 2016).

But these kinds of drivers are often not officially recognised - indeed, they may be expressly precluded by international and domestic law (Leerkes and Broeders 2010, Guild 2016). To comply with the rule of law, immigration detention should be an administrative, non-punitive measure, used for particular 'legitimate aims', i.e. 'to carry out entry or removal controls effectively.' (Fordham et al 2013: 58). People may be detained for removal where this is achievable, and diligently and expeditiously pursued. Any detention must be necessary for the purpose of removal (and not merely administratively convenient), i.e. the person must be deemed likely to abscond; and it requires 'due appraisal of the individual circumstances', i.e. prohibiting blanket detention policies for particular groups (Fordham et al 2013: 39). Whatever the unofficial drivers of detention policies, richer states regularly invoke these principles in defending their use of detention.

Evidence from around the world points to the importance of scrutinizing such claims. For example, the US has long imposed mandatory detention pending removal of non-citizens convicted of certain prior crimes. Koulish's analysis (2016a) found that these were sometimes committed many years before the person came into ICE custody and varied widely in seriousness: suggesting that $42 \%$ of those mandatorily detained could have legal challenges to that classification. Ironically, mandatory detention continued after the introduction of a Risk Classification Assessment (RCA) tool, which 
purported to provide a systematic means of assessing public safety and flight risk, to reduce detention and tailor it to public safety concerns. When ICE apprehends someone, a computerized algorithm assesses safety and flight risk, recommending detention or release, any bail amount, and detention/supervision levels. Koulish (2016b) found that the computer over-detains, rarely recommending release. Strikingly, those mandatorily detained were not deemed by the RCA more dangerous than other detainees. These kinds of findings raise complex questions about how risk is and should be assessed as a basis for detention.

While sharing some other important features with the US and Australia, the UK has not developed mandatory detention policies or computerised assessments; it claims to operate an individualised riskbased approach, with criteria set out in policy guidance and implemented by immigration officials (Mainwaring and Cook 2018). ${ }^{1}$ At the same time decision-making is regularly called into question in court, and by inspections, inquiries and civil society groups. In response the public pressure, the government recently formulated a new mechanism to address risks of harm to people in detention. In the context of COVID-19, hundreds of detainees have been released. As such, the UK thus presents an interesting and topical context to explore how risk is conceptualised and operationalized in detention decision-making.

\section{Exploring the UK immigration and detention system: context and methods}

Over the last three decades, 'Britain's borders have extended, intensified, and deepened' (Allen and Vollmer 2018: 28). Staying in the UK legally has become an increasingly challenging and complex process. The legal landscape is byzantine: 'layer upon layer of inadequately thought out, hastily drafted legislation all too often incompatible with human rights and rule of law guarantees.' (Halsbury's Law Exchange 2016: 5). There has been an intensification of migration legislation; the 'Immigration Rules' changed 5,600 times between 2010 and 2018 (Duvell et al. 2018). The thrust of these changes has been to refine selection and control, with emphasis on tackling 'unwanted' migration: (1) pre-empting via pre-entry screening and refinement of border checks; (2) deterring entry and encouraging departure via in-country 'hostile environment' measures; and (3) enforcing removal via reduction in appeal rights, and use of removal targets and detention.

The Home Office (specifically UK Visas and Immigration, Immigration Enforcement, and Border Force) is responsible for making decisions on applications to enter or remain in the UK, and the enforcement of those decisions. It is widely acknowledged that Home Office immigration work has been 'beset by serious administrative and managerial problems' (Campbell 2017: 28). Political pressure has led to frequent organizational change (Duvell et al, 2018). Mixing traditional bureaucracy and new public management, the management style was described as 'a very crude business culture of outputs, outcomes, targets' by a former border official (Allen and Vollmer 2018: 34). Academic and whistleblower accounts depict a demanding working environment: with overwork, inadequate training, low morale, and chaotic workplaces (Duvell et al. 2018, Hill 2019a and b). Staff must navigate multiple, proliferating sets of guidance, but have considerable discretion in decisionmaking, while their performance targets effectively pressure them to reject applications (Campbell 2017). A leaked Home Office-commissioned review into the Windrush scandal described a 'defensive culture that results in an unwillingness to learn from past mistakes' (Israel 2019).

Scope to challenge Home Office decisions has been increasingly restricted, with progressive removal of appeal rights and dramatic reductions in legal aid. Yet the courts still clearly play an important role 
in reviewing decisions: in the year to March 2019, 52\% of immigration and asylum appeals were allowed (Bulman 2019).

The UK has maintained one of the largest detention systems in Europe: during 2018, 24,748 people were detained in Immigration Removal Centres and prisons; at the end of the year 1,784 were held (Global Detention Project 2016, Home Office 2019a). People's backgrounds speak to the geography of colonial history and contemporary global conflict, with large racialised populations from Afghanistan, Bangladesh, Eritera, Pakistan, India, Iran, Iraq, Nigeria and Sudan, as well as increasingly to European inequalities (Home Office 2019a). Repeated scandals of abuse under private security company management, detention of vulnerable people, lack of a time limit, and cost of the detention estate have prompted growing public criticism (Global Detention Project 2016, Lindley 2019). After three decades of expansion, there has recently been a noticeable decline in detention 'stocks and flows', with the government stating that it is 'committed to going further and faster with reforms to immigration detention' (Home Office 2019b). This downward trend has been temporarily turbo-charged by releases in the wake of COVID-19, a situation I return to in the conclusion of this article.

On what grounds are people detained? Under ECHR 5(1)(f) and UK immigration law, detention is permitted to prevent unauthorised entry or hold someone with a view to removal/deportation. But the legal framework leaves much to be defined by administrative guidance. The Enforcement Instructions and Guidance Chapter 55 suggests that in deciding whether to detain someone pending removal (which is what this article focuses on), decision-makers should consider: (1) likelihood of the person being removed and the timescale, (2) likelihood of the person not complying with conditions of immigration bail, (3) likelihood that the person may offend while on immigration bail, and (4) whether the person is under 18 or an adult at risk (Home Office 2019c). Thus decision-makers are charged with predicting the future, based on migrant characteristics, past behavior and the way immigration bureaucracy works.

In terms of the process, detention decisions are now reviewed by a Gatekeeper 'who acts independently from referring and case working teams to ensure an individual's suitability for detention has been fully assessed, and any vulnerabilities have been considered' (Home Office $2019 \mathrm{~b}) ;{ }^{2}$ a 'properly evidenced and fully justified explanation of the reasoning behind the decision to detain' should be placed on file; Form IS91R should be issued to the individual, indicating the reasons for their detention and factors supporting these; and monthly reviews should be carried out (Home Office 2018c: s6.3). Gatekeepers currently reject $4 \%$ of referrals for detention from caseworkers: the Home Office argues is the result of sound referrals; campaigners highlight issues with removal rates and vulnerabilities (HAC 2019).

Immigration detention typically takes place 'without the normal due process safeguards commonly demanded in liberal democracies' (Wilsher 2012: ix). In the UK there is less judicial oversight for immigration detention than detention in prison and mental health settings. There is scope to apply for a Judicial Review of the lawfulness of a detention (i.e. for a judge to scrutinise the Home Office's adherence to policy and procedure) which is an individual right of petition calling for specialist legal representation, something detainees may struggle to access, and can be a lengthy process (Lindley 2017). Even so, there are well over one hundred cases of wrongful detention and millions of pounds of compensation paid out each year (HAC 2019: 26). People may also apply for bail to the First-tier Tribunal, which assesses the risks of releasing the person, considering 'in the round' the likelihood of the person failing to comply with a bail condition, offending or causing the public harm, and any other matters the Tribunal thinks relevant; of thousands of bail hearings each year, more than half are 
granted, ${ }^{3}$ accounting for around a quarter of all releases from detention (Clements 2018: 2, HMCTS 2019, Home Office 2019a). There has been fresh guidance and training for bail judges in recent years (Lindley 2017).

In-depth primary research into the decision process would require extensive observation and interviews with immigration officers. The present analysis instead draws on published information (administrative guidance, government statistics and an abundance of other sources: inspection reports, independent reviews and parliamentary inquiries as well as academic and NGO research). This is complemented by interviews with close observers (carried out in 2017-2019, the majority as part of research commissioned by the Bar Council of England and Wales, see Lindley 2017).

Twenty lawyers and NGO workers with experience of supporting people in detention were interviewed: as 'repeat players', they had extensive experience of arguments and evidence used by decision-makers and some insight into the experiences of people detained (cf. Ryo 2016). ${ }^{4} \mathrm{After}$ a close reading of reports documenting the experiences of people detained and attendance at an exdetainee conference, five people were interviewed who had first hand experience of being on immigration bail or being held in an immigration detention centre. Finally, having observed several bail hearings, I interviewed three judges with experience of bail applications. ${ }^{5}$

Interviews were digitally recorded, ${ }^{6}$ transcribed and NVivo was used to code material for the different reasons for detention explored in this article, as well as additional themes arising in the course of analysis. Research participants consented for the information to be used in publication; anonymity is maintained, except where it is relevant to identify a participant or organization, with permission.

From this literature review and interviews, insights into how decisions are made and experienced begin to emerge and it is possible to highlight various issues as regards the risk evaluation; it is harder to determine the precise extent of these issues. In the next sections I explore, for each key area: the basic premises of risk evaluation; Home Office policy and practice and judicial oversight; and issues raised by this.

\section{Probability and timescale of removal}

The broad premise of removal is that states have a sovereign right to determine who may live on their territory (De Genova 2016). For the immigration authorities, failure to remove poses risks: exacerbating competition for public and private resources and jobs, and creating a potentially dangerous underclass. Detention functions as a means of containing these 'risky bodies' pending removal. People may be removed from the UK if they did not have any leave to remain and have not applied for any, if the leave that they had has expired, or if their application for (further) leave has been refused.

There are broad critiques of how the state currently exerts its removal powers, which note the erosion of access to refugee protection; the tendency to punish the undocumented more than their employers; the divisive impact on wider society of increased surveillance / hostile environment measures promoting removal; and the UK's involvement in colonialism and on-going global structural inequalities that account for much unauthorised migration (Anderson 2013). Moreover, arguably the byzantine nature and constantly changing landscape of UK immigration law and bureaucracy produces illegality, with small application errors or omissions transforming a someone into an 'illegal migrant', and a bureaucracy that is regularly found to have made mistakes in processing applications (Yeo 2017, Campbell 2017). 
How does this system assess the prospect of removal? The Hardial Singh principles, the key common law constraint on the use of detention powers, stipulate that when someone is detained for removal, the Home Office must pursue this with diligence and expedition, and release the person if it cannot remove them within a reasonable period. Administrative guidance states that people should only be detained when there is 'realistic prospect of removal within a reasonable period' (Home Office 2018: s2). But the nature of a realistic prospect and a reasonable period is not defined. Various obstacles can prevent the issuing of removal directions. These may be legal, e.g. an appeal pending (although not everyone can appeal in-country), a fresh claim that needs to be resolved, a judicial review or injunction suspending removal. They may be logistical, e.g. the need to arrange travel documents and return with the relevant embassies and consulates which work to varying timescales and may refuse to cooperate.

Predicting prospects and timescale for removal can be a complex business. Many people are detained who have not been given notice of removal directions. Some people issued with removal directions but these are later cancelled (Turnball 2018). While imminent removal may be given as a broad reason for detention on Form IS91R, the underlying factors considered as supporting this are not listed. Evidence to parliamentary enquiries suggests that the decision-making process remains opaque, with IS91R appearing to be a 'tick box' exercise: the documentation simply states that removal is imminent, without providing justification (HAC 2019, JCHR 2019). Monthly reviews are designed to revisit the reasons for detention, but lawyers interviewed were skeptical: 'Sometimes you'll look at a case and you'll see that the Home Office has been trying to remove someone for months or years. They are not making any progress, but... say... removal remains imminent...' (see also JCHR 2019). Indeed, this (unlawful) state of affairs was recognised in a leaked letter to the Prime Minister in 2017, by then-Home Secretary Amber Rudd stating 'I have instructed IE [Immigration Enforcement] to renew its focus on removability in order that beds are not being blocked by illegal migrants that we have no realistic hope of removing from the country. This means that those with no near-term prospect of removal would be released into the community on strict reporting restrictions.' (Rudd 2017: 2). An Inspector noted 'consistent issues around the efficiency of the Home Office caseworking' which could delay release or removal (HAC 2019: 56).

The question of removability can be challenged via Judicial Review, scrutinising the timeline for the substantive immigration case, or how diligently the Home Office has pursued removal. But the goal posts are unclear. Unusually, a case in 2009 ruled that 30 months was at the outer limit of the period which could be justified, except where there had been serious offending, but this has not become a rule of thumb; similar cases have produced different judgments regarding reasonable periods (Detention Action 2015). A Detention Action director noted that in proliferating unlawful detention litigation in 2011-2015 'judges [were] initially... horrified that migrants are being detained for administrative convenience for these periods and then [became]... increasingly inured to it... we need a clear lead from parliament about what... [is] acceptable... (APPG 2015: 18).

What are the outcomes of all this? While under the rule of law 'there is no general power to lock people up to make them obey the law', and there is complex case law on this topic, it seems logical that where detention prolongs, this may in grind some individuals down into accepting removal (Costello 2015: 176; Turnball 2018). But, in aggregate, decision-makers' predictions about imminence of removal do not appear to be particularly reliable. Despite concerted efforts to promote removals, the last five years have seen a downward trend (Walsh 2019). Of all of the people leaving detention in 2018, only a third were being removed after less than a month in detention (Home Office 2019a). Figure 1 shows that in 2015-2018 less than half of the people leaving detention were put on a 
flight; the majority were released into the community, by the Home Office or a judge. It seems 'detainability is as much entangled (and sometimes even more so) with un-deportability as with actionable deportability (the prospect of actual deportation)' (De Genova 2016: 6). This has deep social consequences for many people detained, in fear of both precipitous return and endless detention; and people living in the community, in fear of detention as well as removal (Griffiths 2014; Yuval Davis et al. 2019).

\section{Figure 1. Reason for release from detention}

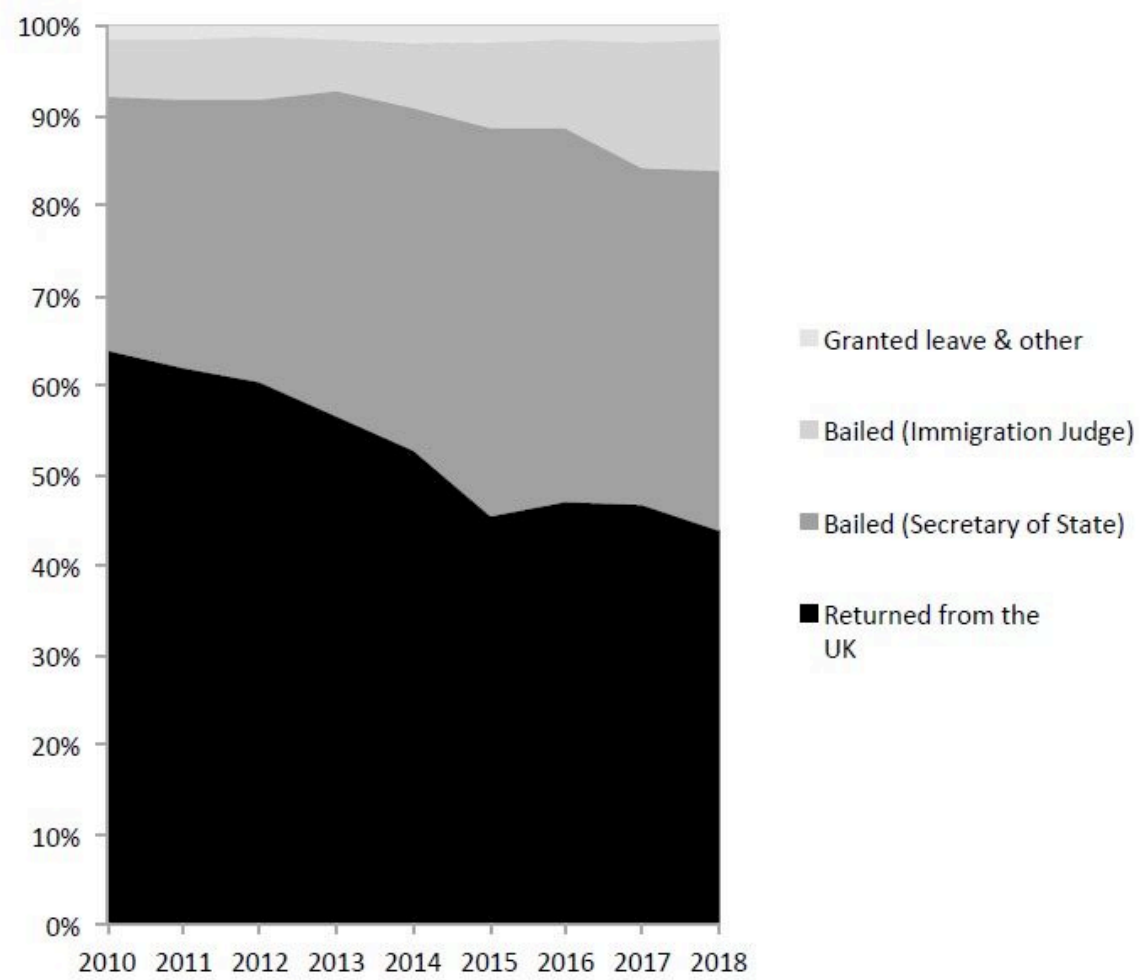

Source: Home Office 2019a. Detention Table 6.

\section{Risk of absconding}

A second key consideration for detention decision-makers is the risk of someone not complying with the conditions of bail, particularly absconding, i.e. failing to report or appear for interviews as requested by the immigration authorities. In 2016, there were almost 60,000 'declared absconders' registered in the Police National Computer (ICIBI 2017). Absconding is seen as harmful because it complicates moving forwards with immigration casework and, where deemed necessary, removal. It is also perceived as undermining the legibility of the population (Scott 1998) and suggests the existence of an underclass of highly insecure and exploitable people.

There are some issues with these premises. Some 'absconders' actually do leave the country, but without informing the immigration authorities (Costello 2015). Others had asylum or personal/family life claims turned down but remain because they are genuinely fearful of removal to a country where they would be in danger, or that they do not know having lived much of their lives in the UK (Lewis et al. 2015, de Norunha 2016). Some people have not been able to obtain legal status but also know that they cannot be legally removed (Detention Action 2015). People in such situations experience 
stress and uncertainty that can drag on for months or years, during they may be destitute, reliant on social networks, or forced to work illegally. Particularly if unable to access state living support or legal aid representation, people may feel that little benefit can come from attending rudimentary reporting appointments, and indeed fear being detained at the appointment (Lewis et al. 2015, ICIBI 2017). Thus the immigration system operates in ways that can 'produce' absconding and precarity (De Genova 2016).

How does the detention policy framework engage with the risk of absconding? Note that preventive incapacitation is usually acceptable only 'to prevent very serious risks from materializing, on a high standard of proof' (Costello 2015: 176). While risk of absconding is often 'a legally vague notion' (Bruycker et al. 2015: 69), UK Home Office administrative guidance in fact specifies that there must be 'strong grounds for believing that the person will not comply with conditions of immigration bail' and sets out criteria for assessing this risk (Home Office 2019c). These include compliance record, i.e. previous failures to comply with conditions of immigration bail (e.g. reporting; work, study or residence restrictions; electronic monitoring) ${ }^{7}$ other immigration law breaches (e.g. illegal entry); and, more positively, history of prior compliance with immigration control requirements (e.g. having applied for visa extensions and further leave on time in the past) (Home Office 2019c). Legal and personal circumstances should be taken into account: outstanding legal claims 'might afford more incentive to keep in touch than if such factors were not present' (Home Office 2019c) and having close ties with family in the UK and a settled address may make someone less likely to abscond (Home Office 2018c).

How does this play out in practice? Note many forms of past non-compliance are the understandable outcomes of people navigating a complex and changing immigration system, and do not automatically imply a greater absconding risk in the future (e.g. using a false document as the only way to enter the UK to claim asylum; breaching visa conditions while under the control of traffickers; overstaying a visa to remain part of your child's life while trying to regularise; missing a reporting appointment because of an emergency). Many people who have some record of noncompliance are not detained ' $95 \%$ of people liable for removal at any given time are managed in the community' (Home Office 2019b). It is often unclear to lawyers why a detained client was deemed to be a higher absconding risk than clients on immigration bail. As regards legal and personal circumstances, lawyers interviewed noted that the Home Office routinely evokes scepticism about the likelihood of success of detainees' outstanding claims; for instance, many immigration claims revolve around family rights but 'Decision-makers often undervalue or mistrust as opportunistic the private and family lives of foreign men, particularly in immigration enforcement cases. Gender, racial and class biases are apparent.' (Griffiths and Morgan 2017: 3). Overall, while criteria are set out for assessing absconding risk, there is a lack of precision regarding inferences to be drawn from them, and how this should be weighed up against other considerations (Costello 2015). The natural conclusion is that a lot of discretion is involved.

The bail hearing constitutes an important check, with absconding risk the most prominent argument used to oppose release (BID 2012, BOP 2013). Both lawyers and judges interviewed noted that this is quite often based on claims that do not stand up to closer scrutiny, e.g. statements are made that the individual had absconded when they may have missed a single reporting appointment; that enforcement activity took place, when actually the person was picked up on reporting or at their address; that the detainee was not complying with the travel document process, when the detainee says they did not receive the appointment information in time; that detainees lied about their identity, when this arises from dual/disputed nationality or variation in identification systems around the world. 
Often evidence on such issues appears to be effectively hearsay, rather than coming from recorded interviews or detention files. While the judges interviewed were sensitive to this, lawyers noted: 'the amount to which a patchy record [affects] a decision to grant bail ... [tends] to vary quite a lot.' Judicial guidance provides a rare rule-of-thumb regarding what might constitute a reasonable period of detention, stating that three months is substantial and six month long (Clements 2018). But frustrated lawyers suggested that some judges accept that Judicial Review proceedings will take place in several months, but still refuse bail: 'time and time again it's as if judges haven't read the guidelines.' Judicial guidance was redrafted in 2018 , and is comparatively concise and clear, including useful notes on how to integrate absconding risk assessment with particular bail conditions (Clements 2018), although the extent to which this is shaping practice is hard to ascertain. Opportunities for feedback learning for judges are scant: it is rare they would find out that someone they granted bail later absconded (BID 2012).

Does detention contain people who would otherwise have absconded? Systematic research on compliance and absconding, which might inform decision-making, is limited (Duvell et al. 2018). Ryo convincingly argues that to understand why people obey or disobey the law, we need to take a more 'subject-centred' approach, examining their beliefs, values, perspectives and experiences (2017: 285). Her research suggests that for unauthorised migrants in the US, typically their status does not arise from general disrespect for immigration law and the national sovereignty, but from pressing survival and family responsibilities that for the individual morally outweigh the former. Thus immigration laws that give people scope to achieve reasonable goals (to work, to be present with their families, to be safe from harm elsewhere) are much more likely to be complied with; bias, arbitrariness and unpredictability in immigration policy landscapes fosters 'legal cynicism' and resistance (Ryo 2017).

Detention is not the only means of keeping track of people liable to removal - it is a relatively draconian, expensive and alienating approach. '[A]s in all instances of preventive detention, we will not always be right, so we will lock people up who would have turned up for their hearings, and been entirely cooperative in the process. The danger of false positives is high.' (Costello 2015: 166). An internal evaluation of a Home Office release project in the mid 2000s found that it would not have been possible, based on the details of each case, to predict in advance who absconded (BID 2012). The Home Office reports general compliance with reporting requirements of over $90 \%$, remarkably similar to those of pilot projects where detainees have been released, and evidence from other national contexts. ${ }^{8}$ It is clear that detention is not a functional inevitability: there is a wide spectrum of alternative ways of keeping track of people (Flynn 2016). Thus many organisations advocate for community-based case management approaches to reduce the number of people in detention and ensure prompt access to necessary advice and support, arguing that this leads to better outcomes in terms of well-being during the immigration process, eventual grants of leave to remain, as well as cooperation with negative decisions as people are 'satisfied that all options to remain in the UK have been fairly explored' (Ohtani and Phelps 2016: 34). This seems to be borne out by international evidence and has gained some traction with government which is piloting small-scale 'alternatives to detention' projects for specific groups (Edwards 2011, Home Office 2019b).

\section{Risk of offending}

The increasing salience over time of a discursive association of immigration, crime and threat in the UK and elsewhere is well-documented (Anderson 2013, Vollmer 2017). After revelations in 2006 that 
over 1,000 foreign national prisoners had been released from prison before the Home Office had considered them for deportation, provisions were brought in whereby non-citizens with a criminal record are prioritised for expulsion (Aliverti 2012). In many cases, former offenders are administratively detained in prison or transferred to a removal centre at the end of their sentence: around half of detainees are ex-offenders (HAC 2019). Thus, imprisonment, administrative detention and deportation are seen to operate in tandem as a way of protecting the public from harm in both the shorter and longer term.

There are issues with these premises. First, the discursive association between immigration and crime is empirically questionable (Ignatans 2018). Yet there are concerns that the way the social care system and hostile environment operate may push some towards offending (de Norunha 2016, ICIBI 2017). Second, there are issues of fairness, given that offending is dealt with already by the criminal justice system: adding detention on top of deportation arguably constitutes triple punishment.

What is the policy framework as regards risk of offending? Foreign nationals who have served a sentence of 12 months or more are automatically scheduled for deportation ${ }^{9}$ and generally further detained on administrative grounds in prison or a detention centre (Aliverti 2012). Administrative guidance requires decision-makers more generally to consider offending risk, including 'the likelihood of harm and the seriousness of the harm if the person does offend' (Home Office 2019c: s3.1). If a very minor offence has been committed, it may be viewed as more relevant to absconding than offending risk. Guidance steers caseworkers particularly strongly towards detention of people who have committed a violent, sexual, drug-related or other serious offence, where bail is likely to be appropriate 'only in exceptional cases' and 'what constitutes a 'reasonable period'... may last longer than in non-criminal cases' (Home Office 2019c: s3.2.1 and 3.A).

In practice, several lawyers interviewed perceived that increasingly people were being detained following any offence which leads to criminal prosecution, including minor offences such as shoplifting, and that even past arrests which did not lead to a conviction, or people having mental health problems or kicking off in detention (even though detention might be the reason for this) were being used to classify people as risky for release. Medical Justice (2019) cite the example of an Iraqi torture survivor who after 15 years in the UK was detained three times (for 50 days, 28 days, and 10 days) based on a violent event 10 years previously; the sentence was long finished, and the individual had since complied with reporting restrictions. Lawyers' accounts suggest that decision-makers' assessment of offending risk are often static, relying on past offences, disregarding personal development and research evidence on desistence from crime. Empirical research on non-citizen reoffending is sparse, and there is no body of evidence regarding misconduct while on immigration bail (Ryo 2016). But wherever possible assessment of risk of harm to the public is supposed to be carried out by National Offender Management Service, based on Offender Assessment System (OASYS) report, the pre-sentence report, or other sources, including the Offender Group Reconviction Scale (Home Office 2019c: s3.2.12). Such evidence, and the Harm Matrix it is supposed to help populate, is rarely provided in bail hearings. Bail for Immigration Detainees concluded: 'The HO don't want to disclose information to do with risk. They ignore us when we request the information... [or] say make it through a Subject Access Request, [which] could take 40 days or more... [they] fight tooth and nail to avoid disclosure... it suggests... there's no rigorous system of keeping [this information] and they don't want their files to be open to scrutiny.' Again this does not seem to fit with the high evidence threshold supposed to justify preventive incapacitation.(Costello 2015).

When this question comes to court, judicial guidance states that where professional reports are not available, bail judges should consider the date of last conviction(s), behavior since, impact of 
convictions on the public, and absence or presence of risk-reducing support or guidance (thus including more 'dynamic' factors, e.g. evidence of personal development in prison, planned community-based support, contact with family and financial guarantors). Judges seem to vary in their approaches. One judge interviewed stated that people must have 'a pretty shocking criminal record' to be refused bail on grounds of risk of public harm. But several lawyers interviewed said that many immigration judges, charged with preventing 'future crime', regard repeat but very minor offending much more seriously than criminal judges, intimating the possibility of a similar judicial heuristic to that discerned in US bond hearings, where any prior criminal record became a mental shortcut to predict dangerousness and flight risk (Ryo 2016). One lawyer noted: '[T]here's a lot of emphasis... the more serious the risk, the longer that they have to stay in detention... [even when] you're unlikely to get any progress [on deportation] for a very long time. It's like Minority Report... why on earth should immigrants be subjected to these things by people who aren't even criminal justice experts or psychological experts...?'

The outcomes raise concerns. Most people detained for very long periods have some kind of criminal record and the Home Office is trying to deport them, but there are legal or logistical barriers (Ohtani and Phelps 2016). One person detained for over three years commented: 'Detention is worse than prison, because in prison you count your days down and in detention you count your days up... and up... and up' (Souleymane 2015). The government sees little rationale for rehabilitative activities (Bosworth and Turnball 2014). Ultimately, some people are expelled from the UK, stigmatised and ill-equipped to re-integrate in their country of citizenship (de Norunha 2016). But some are eventually released, ill-prepared for resuming life in the community, often after their licence conditions have expired. They may be heavily alienated: 'Detention destroyed all my trust in the system. It made me think twice about reporting just in case they handcuff me up again. I absconded. I re-offended.' (Ohtani and Phelps 2016: 6). All this arguably puts the migrant and public at greater risk. Meanwhile, as with absconding risk, there are indications that much may be achieved by community-based case management: in a Detention Action Community Support Project with ex-offenders who had experienced or were at risk of detention, 19 of the 21 participants did not re-offend (Ohtani and Phelps 2016).

Whereas absconding and offending risk militate against release, the next section considers the risk of harm to the migrant, which militates in favour of release.

\section{Risk of harm to people detained}

The government acknowledges that detention may have detrimental effects on the individuals detained, and that in some cases it is not appropriate to detain people because of the harm this may cause the individual. Administrative guidance stated for many years that people with serious vulnerabilities should only be detained in 'very exceptional circumstances'. However, conditions in UK detention centres have been repeatedly criticised, including evidence of poor healthcare, abusive treatment of detainees, and damaging psychological legacies (APPG 2015). The experiences of those with prior trauma and clinical health issues have come in for particular scrutiny (HAC 2019). In six cases, the High Court found detention conditions amounted to 'inhuman and degrading treatment' and the UK's failure to protect vulnerable people drew UN criticism (Medical Justice 2018). Following an independent review of the welfare of vulnerable persons in detention, the government committed to improving conditions in detention and announced the introduction of an 'Adults at Risk' policy with the purpose of ensuring 'fewer people with a confirmed vulnerability will be detained in fewer 
instances and that, where detention becomes necessary, it will be for the shortest period necessary.' (Home Office 2016: pt 6, Shaw 2016).

The policy has three main components. First, it provides a list of conditions and experiences that indicate that a person may be particularly vulnerable to harm in detention: people suffering from a mental health condition, impairment and post traumatic stress disorder; people with serious physical disabilities, health conditions or illnesses; being pregnant, aged 70 or over, or a transsexual or intersex person; victims of torture, sexual or gender based violence, human trafficking or modern slavery; and people suffering from 'unforeseen' vulnerability (Home Office 2016). Second, the policy introduced three levels of evidence: (1) self-declaration; (2) professional evidence or official documentary evidence; and (3) professional evidence that the person is an adult at risk and that detention is likely to cause them harm (Home Office 2018b). Third, caseworkers must balance vulnerability evidence against 'immigration control factors', i.e. expectations regarding removal and risk of non-compliance or offending (Home Office 2018).

How has this worked in practice? It would appear that the list of categories reaffirmed existing guidance, while flagging additional categories and adding a catch-all category suggesting increased openness regarding what constitutes vulnerability. Yet controversially, a narrow definition of torture was adopted, focusing on acts perpetrated by or with the acquiescence of state actors, excluding victims of non-state actors. Although this was found unlawful (as it excluded people covered by the previous policy, contrary to the purpose of the Immigration Act 2016, and lacked rational or objective evidence base) wrangling over the definition of torture continued (Medical Justice 2018).

As regards evidence of vulnerability, gatekeepers rely on pre-existing internal information, rather than active screening. Research suggests where there is vulnerability evidence on file, this may not necessarily be passed on by the casework team or taken into account and it is rare that gatekeepers prevent a detention on vulnerability grounds (BID 2018, Medical Justice 2018, Shaw 2018). A whistleblower highlighted problems with internal information systems: 'the cupboards were stacked with documents that we simply didn't have time to deal with. Often we found medical reports from Freedom from Torture, which had been overlooked in the chaos and hadn't been linked to the applicant's file. This means their application potentially went through without all the information needed to make a fair decision.' (Hill 2019a).

Once someone is detained, it is well-recognised that trauma, stigma, language and lack of legal advice may impede self-declaration (BID 2018). Moreover, detainees face an uphill struggle obtaining professional assessment of their health and risk factors. Detention centre doctors must report to the Home Office on any individual whose health is likely to be harmed by detention (Rule 35/1), who is suspected of suicidal ideation (Rule 35/2) or who in the doctor's view may be a victim of torture (Rule 35/3). But the Rule 35 system appears to be generally under-utilised and the vast majority of reports relate to torture (HAC 2019). ${ }^{10}$ Even where professional evidence of vulnerability is obtained, this is rarely recognized as Level 3, for a various reasons: some people may be recognized as fitting a category but display great personal resilience without obvious signs that detention is harmful to them; medics may fail to complete the form correctly or be professionally cautious about making definitive statements about likelihood of harm (deeming it hard to predict without more specialist expertise) (BID 2018). Caseworkers may read Rule 35 reports sceptically: designating as Level 2 people with wide-ranging conditions and experiences, including florid psychiatric symptoms (HAC 2019). ${ }^{11}$ Independent medico-legal reports may address these gaps but take time and support to procure. Thus although Level 3 is phrased preventatively, i.e. that detention is likely to harm the person, evidence of 
this is generally only obtained once someone is detained, and their condition is already deteriorating a 'wait-and-see' approach (Medical Justice 2018).

In terms of the balancing vulnerability against immigration control factors: previous sections highlighted a range of issues regarding removal predictions and absconding and offending risk assessments. Only Level 3 evidence seems to be afforded significant weight, akin to the previous policy's 'very exceptional circumstances' requirement, i.e. outweighed by having a removal date set in the 'immediate' future, no barriers to removal, and/or significant public protection concerns (BID 2018, Medical Justice 2018). BID found this balancing in practice a 'superficial exercise' in particular noting that 'Previous offending tended to automatically outweigh any well-being concerns, regardless of the seriousness of the offending or the risk to the detainee's health if detention was maintained.' (2018: 4).

There is no prompt or automatic judicial oversight of the prospect of harm to the individual. It is not a consideration in bail hearings. It may form the basis of a Judicial Review claim: in numerous cases, before and after the introduction of the Adults at Risk policy, detention has been found retrospectively to be unlawful on these grounds; many more cases are settled out of court (HAC 2019).

In terms of outcomes, the government does not yet seem to have achieved its stated goal: Shaw's follow-up review noted 'a gap between the laudable intentions of policymakers and actual practice on the ground... I was told by IRC staff and managers that there has been little change in the number of vulnerable individuals in detention.' (2018: ix). An interviewee from the Immigration Law Practitioners' Association commented less sympathetically: 'vulnerable has become a term of art for the Home Office'. The state's adoption of the language of harm and protection can be 'deeply problematic when, through immigration controls and practices, the state is implicated in constructing this vulnerability' (Anderson 2012: 1241). Where individuals are harmed by detention, this has implications for their families, and communities where they will later live, whether in the UK or abroad. As one person with first-hand experience of detention put it, 'The mental state of some people in detention is alarming... Running out from a system of a country where you never see headway, and then this country who came into your country for some reason or another, created wars, anger... seeking refuge, and you are being treating like this. Knowing what you have in your family. It rips you apart. They ought to look at the mental stability of many people that they put behind, and what they are creating... You have different levels of what people can take... And when people have responsibilities, having family, having children... That pressure becomes so overwhelming that it's beyond anything anyone could comprehend. They may say, oh it's just detention and we provide meals. But look at the real symphony of it.'

\section{Conclusions: 'The real symphony of it'}

In the context of heavy contestation around the role of risk in immigration detention governance, this article has drawn on UK published reports and interviews with close observers, to explore how decisions are made and experienced, focusing on questions of removal, flight, offending and harm. While risk is undoubtedly a prominent theme in political rhetoric and administrative guidance, the analysis here suggests that risk assessment in detention decision-making is very far from a well-oiled, reliable machine. Indeed, after a long interview, one NGO worker concluded 'This risk thing is an absolute wild west, isn't it?' 
Some issues were raised with basic premises. Emphasising the desirability of removal overlooks the ways that global geopolitics and the complexities of the immigration regime conspire to produce illegality. Emphasising absconding risk as a rationale for detention ignores more constructive options for engaging with migrants. Imposing detention as well as deportation on ex-offenders arguably amounts to triple punishment. While it is indeed clear that detention can harm people, focusing on protected categories may divert attention from the need for stronger, universally applicable safeguards.

Even if one accepts the broad premises of the current detention system, there are issues with Home Office policy and practice as regards risk evaluation. Immigration officers doggedly insist on reasonable removability, the core rationale for detention, often in the face of substantial legal and logistical obstacles. Concerns arise in relation to low standards of evidence used to support claims about immigration control risks. This contrasts with a demanding approach to evidence of individual vulnerability to harm in detention, and a system still poorly equipped to assess this effectively. To outsiders, the process lacks transparency, with apparently high levels of bureaucratic discretion to evaluate and balance up the multiple risk factors, within a wider institutional environment geared towards removal. Yet the US experience, where efforts were made to develop a more 'scientific' tool to reduce detention, suggests the real problem is not the need for more refined risk methodologies, but the tension between the sovereign bias (the "extraordinary power [that the state wields] over noncitizens territorial borders and within boundaries') and the rule of law (Koulish 2016b: 1). Meanwhile, there is a lack of prompt, automatic judicial oversight of the lawfulness of UK detention decisions. While bail hearings are a relatively accessible process, there is still evidence of inconsistencies and variation in approaches to assessing removability and immigration control risks. Higher courts provide some check on whether the Home Office is following its policies and procedures, and ways of challenging some policies, but it is a constant struggle, and one which many detainees lack means to access.

In terms of outcomes, as noted in the Netherlands: 'Given the persistence - and widening - of the gap between the large investments in immigration detention and the declining 'proceeds' thereof in terms of expulsions, the policy does seem to lack rationality.' (Leerkes and Broeders 2010: 836, see also Mainwaring and Cook 2018). Indeed, there are hints that UK government policy efforts, officially intended to bring the risks that immigration is deemed to pose under control, are generating new areas of unpredictability (cf. Beck 1992). Efforts to narrow opportunities for legal migration, intensify enforcement, and promote a hostile environment create fertile grounds for exploitation (Lewis et al. 2015, Yuval-Davis et al. 2019). Detainability, compounding deportability, is a distinct 'lived experience... characterised by profound uncertainty... and perceived inconsistency and arbitrariness', eroding people's trust (Turnball 2018: 5). This points to the need to take much more seriously the risks the current immigration and detention system poses, both to those subject to its rigors and to social cohesion and safety in wider society.

In broad strokes, this analysis supports the claim that while the concept of risk permeates detention rhetoric and governance in important ways, it fails to fully explain why countries adopt and persevere with detention. The analysis hints at a complex mixture of other more informal motives, also worthy of further investigation and scrutiny, particularly in light of the potential counter-arguments, which are touched on below.

Flying in the face of legal best practice, immigration detention is arguably 'routinely coercive and preventive', seeking to ensure compliance and prevent offending (Costello 2015: 176). This has a significant cost, however, in terms of alienation of those incarcerated, many of whom in the UK context are later released to live their lives in the community. 
The logic of deterrence looms large in detention policy - despite being generally against international human rights law and empirically debatable: 'there is no empirical evidence that the prospect of being detained deters irregular migration, or discourages persons from seeking asylum' (Edwards 2011: 117).

Detention may also have be a more politically performative function, with detention projecting tough control of immigration: 'penal management of foreigners elicits less resistance and even generates support for such punitive policy among the precarious fractions of the native working class that constitute its main foil.' (Waquant 2009, 51; Leerkes and Broeders 2010). This too is on shaky ground: both because people often modify attitudes when confronted with the human costs of immigration enforcement, and because in a diverse society, restrictive measures ostensibly targeting 'unwanted' migrants tend to have much wider impacts on citizens of racialised minorities and the wider public (Anderson 2013, Ellerman 2006).

Detention has also sometimes been seen as a means of managing poverty (Leerkes and Broeders 2010); however, this does not seem to be a concern in the UK where the Home Office itself regularly releases detainees to the streets, and impoverishment has been explicitly part of a hostile environment geared to encourage voluntary departures (Lindley and della Croce 2019).

Finally, commentators have long noted that a largely privatised detention industry creates its own momentum (Menz 2011, Flynn 2016): there are strong suggestions in the UK that 'the size of the detained population is determined more by the available bedspace, rather than any in-depth analysis of need.' (Shaw 2018: 8). However, these relationships are also under pressure, with private sector abuse and costs an increasingly prominent element in campaigns for reform (HAC 2019).

With so many possible functions of detention increasingly obviously on shaky ground, little wonder that pressure for change has been growing (Lindley 2019). As I finalise this article, the detention system is at a key juncture. With the pandemic policy response gearing up in March 2020, campaigners argued that global travel restrictions prevented removal and detention posed real risks of harm from catching COVID-19. Within a short space of time, hundreds of detainees were released by immigration officers or by bail judges, and numbers in detention dropped to 368 by May (Taylor 2020). But people are still being detained and deported and there is no guarantee that detentions will not increase further as travel bans lift (Detention Action 2020). The radical downsizing of detention may be one of the 'silver linings' of 'lockdown', reinforcing the possibility of engaging differently with people during the immigration process. Whether this gets 'locked in' as a societal shift is another question.

Acknowledgements: I am grateful all research participants for their time and insights; Antonia Harris and Pegah Rajabi research assistance; and participants at the Royal Geographical Society Annual Conference Aug 2018, IV CINETS Conference 'Mobility and Security in an Era of Globalization Crimmigration at a Crossroads?' Oct 2018, SOAS Centre for Migration and Diaspora Studies seminar Dec 2019, COMPAS University of Oxford Mobility Research Day Mar 2019, and Bristol/UWE Risky Relationships Workshop Mar 2019 for their input.

Funding Statement: The Bar Council of England and Wales commissioned research on which this paper draws, resulting in the report published in November 2017: 'Injustice in Immigration Detention: Perspectives from Legal Professionals'. 


\section{References}

Aliverti, A. (2012) 'Exploring the Function of Criminal Law in the Policing of Foreigners: The Decision to Prosecute Immigration-related Offences', Social \& Legal Studies 21/4: 511-527.

All Party Parliamentary Group on Refugees \& the All Party Parliamentary Group on Migration (APPG) (2015) The Report of the Inquiry into the Use of Immigration Detention in the United Kingdom.

Allen, W.L. and B.A. Vollmer (2018) 'Clean skins: Making the e-Border security assemblage' Environment and Planning D: Society and Space. 36/1: 23-39.

Alpes, M.J., and A. Spire (2014), 'Dealing with Law in Migration Control: The Powers of Street-level Bureaucrats at French Consulates', Social and Legal Studies 23/2: 261- 274.

Amoore, L. (2011) 'Data Derivatives: On the Emergence of a Security Risk Calculus for Our Times' Theory, Culture \& Society, Vol. 28(6): 24-43.

Anderson, B. (2013) Us and Them? The Dangerous Politics of Immigration Control. Oxford: Oxford University Press.

Andersson, R. (2014) Illegality, Inc.: Clandestine migration and the business of bordering Europe. Chicago: University of Chicago Press.

Bail for Immigration Detainees (BID) (2012) The Liberty Deficit: Long-Term Detention \& Bail DecisionMaking. London: BID.

Bail for Immigration Detainees (BID) (2018) Adults at Risk: The Ongoing Struggle for Vulnerable Adults in Detention. An Evaluation of the 'Adults at Risk' Policy in Practice. Evidence from BID's Casework. London: BID.

Bail Observation Project (BOP) (2013) Still a Travesty: Justice in Immigration Bail Hearings. Second report from the Bail Observation Project.

Beck, U. (1992) Risk Society: Towards a New Modernity. London: Sage Publications.

Bhui, H. S. (2018) Evidence to the Home Affairs Select Committee in May 2018 from the Inspection Team Leader at HM Inspectorate of Prisons (HMIP), Hindpal Singh Bhui.

Bigo, D. (2002) 'Security and Immigration: Toward a Critique of the Governmentality of Unease', Alternatives: Social Transformation and Humane Governance, 27/1: 63-92.

Bosworth. M. (2014) Inside Detention. Oxford: Oxford University Press.

Bosworth. M. and S. Turnball (2014) 'Immigration Detention, Punishment, and the Criminalization of Migration' in S. Pickering and J. Ham (eds) The Routledge Handbook on Crime and International Migration. London: Routledge.

Bruycker, P. de, A. Bloomfield, E. Tsourdi, and J. Pétin (2015) Alternatives to immigration and asylum detention in the EU: Time for Implementation. Odysseus Network Report.

Bulman, M. (2019) 'More than half of immigration appeals now successful, figure show' The Independent, 13 June. https://www.independent.co.uk/news/uk/home-news/immigration-appeals-home-office-successrate-windrush-migrant-crisis-a8957166.html Downloaded 2 Jan 2020

Campbell, J. (2017) Bureaucracy, Law and Dystopia in the United Kingdom's Asylum System. Abingdon; New York: Routledge.

Clements, Judge M. (2018) Presidential Guidance Note No 1 of 2018: Guidance on Immigration Bail for Judges of the First-Tier Tribunal (Immigration and Asylum Chamber).

Costello, C. (2015) 'Immigration detention: The grounds beneath our feet', Current Legal Problems 68/1: 143177.

Czaika, M., H. de Haas and M. Villares-Varela (2010) 'The Global Evolution of Travel Visa Regimes', Population and Development Review, 44(3): 589-622.

De Genova, N. (2016) 'Detention, Deportation, and Waiting: Toward a Theory of Migrant Detainability'. Global Detention Project Working Paper No. 18. Geneva: Global Detention Project.

Detention Action (2015) 'Indefinite detention? We are in the world of Kafka.' Available at: https://detentionaction.org.uk/2015/09/10/indefinite-detention-we-are-in-the-world-of-kafka/ Accessed 14 Aug 2019

Detention Action (2020) Update: immigration detention, COVID-19 and where we stand now. 12 May, available at: https://detentionaction.org.uk/2020/05/12/update-immigration-detention-covid-19-andwhere-we-stand-now/. Accessed 12 May 2020

Duvell, F., M. Cherti and I. Lapshyna (2018) Does Immigration Enforcement Matter? Irregular Immigrants and Control Policies in the UK. Final Report, October 2018. Centre on Migration, Policy and Society, University of Oxford: Oxford.

Edwards, A. (2011) 'Measures of First Resort: Alternatives to Immigration Detention in Comparative Perspective' Equal Rights Review, 7: 117-141.

Ellermann, Antje (2006) 'Street-level Democracy? How Immigration Bureaucrats Manage Public Opposition.’ West European Politics, 29(2), 287-303. 
Flynn, M. (2014) 'There and Back Again: On the Diffusion of Immigration Detention.' Journal on Migration and Human Security, 2/3: 165-197.

Flynn, M. (2016) 'From bare life to bureaucratic capitalism: analyzing the growth of the immigration detention industry as a complex organization.' Contemporary Readings in Law and Social Justice, 8/1, pp. $70-97$.

Fordham, M. with J.N. Stefanelli and S. Eser (2013) Immigration Detention and the Rule of Law: Safeguarding Principles. London: Bingham Centre for the Rule of Law.

Foucault, M. (1991) 'Governmentality' in G. Burcell, C. Gordon and P. Miller (eds) The Foucault Effect: Studies in Governmentality, pp. 87-104. Chicago: Chicago University Press.

Global Detention Project (2016) United Kingdom Immigration Detention. Available at: https://www.globaldetentionproject.org/countries/europe/united-kingdom Accessed 14 Aug 2019

Griffiths, M. (2014) 'Out of time: The temporal uncertainties of refused asylum seekers and immigration detainees', Journal of Ethnic and Migration Studies, 40/12: 1991-2009.

Griffiths, M. and C. Morgan (2017) Immigration enforcement and Article 8 rights: Mixed-immigration status families. Policy Bristol Policy Report 19: Nov 2017, University of Bristol.

Guild, E. (2016) 'Understanding immigration detention in the UK and Europe' in M.J. Guia, R. Koulish and V. Mitsilegas (eds) Immigration Detention, Risk and Human Rights: Studies on Immigration and Crime, p.141-155. Springer.

Hall, A. (2017) 'Discretion and the Data Border', Security Dialogue, 48/6: 488-504,

Halsbury's Law Exchange (2016) A State of the Nation Report on Legal Aid: Can We Safeguard Access to Justice? London: Halsbury's Law Exchange.

Her Majesty's Courts and Tribunals Service (2017), Freedom of Information Act (FOIA) Request - 170907013

Her Majesty's Courts and Tribunals Service (2019), Freedom of Information Act (FOIA) Request - 190425005

Hill, A. (2019a) 'Toxic atmosphere': the Home Office unit everybody wants to leave.' The Guardian, 28 April.

Hill, A. (2019b) 'Home Office chaos and incompetence lead to unlawful detentions, claim whistleblowers.' The Guardian, 28 April.

Home Affairs Committee (HAC). 2019. House of Commons Home Affairs Committee Immigration Detention Fourteenth Report of Session 2017-2019. London: House of Commons.

Home Office (2016) Immigration Act 2016: Guidance on adults at risk in immigration detention. August 2016.

Home Office (2018a) Detention services order 09/2016 Detention centre rule 35 and Shortterm Holding Facility rule 32 Version 7.0. London: Home Office.

Home Office (2018b) Immigration Act 2016: Guidance on Adults at Risk in Immigration Detention. London: Home Office.

Home Office (2019a) Immigration Statistics, Detention Tables, Jan-Mar 2019.

Home Office (2019b) Factsheet: Detention, 21 March 2019. Available at: https://homeofficemedia.blog.gov.uk/2019/03/21/fact-sheet-detention/. Accessed 30 July 2019.

Home Office (2019c). 'Chapter 55: Detention' in Enforcement Instructions and Guidance, v. 25. London: Home Office.

Ignantans, Dainis (2018) 'Immigration and crime, is there a link?' The Conversation, 10 April. Available at: https://theconversation.com/immigration-and-crime-is-there-a-link-93521. Accessed 30 July 2018.

Independent Chief Inspector of Borders and Immigration (ICIBI) (2017) An Inspection of the Home Office's Reporting and Offender Management Processes, December 2016-March 2017, November 2017. London: Independent Chief Inspector of Borders and Immigration.

Israel, Simon (2019) 'Windrush Scandal: Home Office 'reckless' and 'defensive', leaked review finds' Channel 4 News, 27 Jun 2019, https://www.channel4.com/news/windrush-scandal-home-office-reckless-anddefensive-leaked-review-finds. Accessed 2 Jan 2020

JCHR - House of Commons House of Lords Joint Committee on Human Rights (2019) Immigration Detention: Sixteenth Report of Session 2017-19. London: House of Commons.

Koulish, Robert (2016a) 'Using Risk to Assess the Legal Violence of Mandatory Detention' MDPI Laws Journal, 5(30)

Koulish, R. (2016b) 'Sovereign Bias, Crimmigration, and Risk' in M.J. Guia, R. Koulish and V. Mitsilegas (eds) Immigration Detention, Risk and Human Rights: Studies on Immigration and Crime, p.1-12. Springer.

Leerkes, A. and D. Broeders (2010) 'A Case of Mixed Motives?: Formal and Informal Functions of Administrative Immigration Detention' British Journal of Criminology, 50: 830-850.

Lewis, H., P. Dwyer, S. Hodkinson and L. Waite (2015) Precarious Lives: Forced Labour, Exploitation and Asylum. Bristol: Polity.

Lindley, A. (2017) Injustice in immigration detention: perspectives from legal professionals. A report commissioned by the Bar Council of England and Wales.

Lindley, A. (2019) 'Civic mobilisation around immigration detention: Exploring motivations and experiences' Geoforum, 102: 5-16. 
Lindley, A. and C. della Croce (2019) 'Migrants granted bail left trapped in British immigration detention because of nowhere to go' The Conversation, $7 \mathrm{Mar}$, https://theconversation.com/migrants-grantedbail-left-trapped-in-british-immigration-detention-because-of-nowhere-to-go-110482. Accessed 31 July 2019

Lipsky M. (1980) Street-Level Bureaucracy: The Dilemmas in the Individual in Public Services, New York: Russell Sage Foundation.

Mainwaring, C. and M.L. Cook (2018) 'Immigration detention: An Anglo model' Migration Studies, 1-22.

Medical Justice (2018) Putting Adults at Risk: A Guide to Understanding the Home Office's 'Adults at Risk' Policy and Its History. London: Medical Justice.

Medical Justice (2019) Unprotected: The Failure to Protect Vulnerable Migrants from the Harm of Immigration Detention. London: Medical Justice.

Menz, G. (2011) 'Neo-liberalism, Privatization and the Outsourcing of Migration Management: A Five-Country Comparison', Competition and Change. 15/2: 116-35.

Norunha, L. de (2016) 'Two Flights: The Deportation Game', Lacuna Magazine, March 26. Available at: https://lacuna.org.uk/migration/two-flights-the-deportation-game/. Accessed 14 Aug 2019

Ohtani, E. and J. Phelps (2016) Without Detention: Opportunities for Alternatives. London: Detention Action.

Pécoud, A. and M. Geiger (2010) The Politics of International Migration Management, Basingstoke: Palgrave.

Rudd, A. Letter to the Prime Minister, 30 Jan 2017, Available at: https://www.scribd.com/document/377702336/Letter-from-Amber-Rudd-to-TheresaMay\#fullscreen\&from embed. Accessed 31 July 2019.

Ryo, E. (2016) 'Detained: A Study of Immigration Bond Hearings', Law and Society Review, 50/1.

Ryo, E. (2017) 'The Promise of a Subject-Centred Approach to Understanding Non-Compliance', Journal of Migration and Human Security, 5/2: 285-296.

Scheel, Stephan (2017) "'The Secret Is to Look Good on Paper": Appropriating Mobility within and against a Machine of Illegalization' in Nicholas de Genova (ed) The Borders of 'Europe': Autonomy of Migration, Tactics of Bordering. Durham: Duke University Press, p.37

Scott, J.S. (1998) Seeing Like A State: How Certain Schemes to Improve the Human Condition Have Failed. New Haven and London: Yale University Press.

Shaw, S. (2016) Review into the Welfare in Detention of Vulnerable Persons A report to the Home Office, January 2016

Shaw, S. (2018) Assessment of government progress in implementing the report on the welfare in detention of vulnerable persons. A report to the Home Office. July 2018.

Silverman, S.J. and E. Massa (2012) 'Why Immigration Detention is Unique', Population, Space and Place, 18: $677-686$.

Sørensen, M. P. (2018) 'Ulrich Beck: exploring and contesting risk', Journal of Risk Research, 21(1): 6-16.

Souleymane (2015) 'Immigration Detention is Mental Torture'. Speech to Jewish Community members at JW3 Centre, 8 October 2015, Freed Voices Group.

Stumpf, J. (2006) 'The Crimmigration Crisis: Immigrants, Crime, and Sovereign Power', American University Law Review, 56 (2): 368-419.

Taylor, Diane (2020) 'Home Office accused of pressuring judiciary over immigration decisions' The Guardian, 6 May

Turnball, S. (2018) 'Living the spectre of forced return: negotiating deportability in British immigration detention', Migration Studies, mny024: 1-20

Vollmer, B. (2017) 'The Continuing Shame of Europe: Discourses on migration policy in Germany and the UK' Migration Studies, 5(1): 49-64.

Wacquant, L. (2009) Punishing the Poor: The Neoliberal Government of Social Insecurity. Durham and London: Duke University Press.

Walsh, P.W. (2019) Deportation and Voluntary Departure from the UK. Migration Observatory Briefing, 11 July, University of Oxford.

Williams, A. M. and V. Baláž (2012) 'Migration, risk and uncertainty: theoretical perspectives', Population, Space and Place, 18/2: 167-180

Wilsher, D. (2012) Immigration Detention: Law, History, Politics. Cambridge: Cambridge University Press.

Yeo, C. (2017) Everything You Need to Know about the 'Hostile Environment' for Immigrants. Free Movement (blog). May 29, 2017. https://www.freemovement.org.uk/hostile-environment-affect/.

Yuval-Davis, N., G. Wemyss and K. Cassidy (2019) Bordering. Cambridge: Polity. 


\footnotetext{
${ }^{1}$ An unpublished policy involving a near blanket ban on release of former foreign national offenders was found to be unlawful in 2011 (R (Lumba) v SSHD [2011] UKSC 12, 20-21).

${ }^{2}$ Individuals are rarely assigned to a single Home Office caseworker throughout their immigration case: staff generally make decisions on specific aspects then hand the case to another team and face-to-face engagement with migrants is very limited (Shaw 2018).

${ }^{3}$ Rather than refused. Note however around $40 \%$ of total applications are withdrawn without a hearing, because of some sort of problem (HMCTS 2017 and 2019)

${ }^{4}$ Lawyers were identified through Bar Council referral, Detention Duty Advice rota and independent channels.

5 Judges were contacted with the permission and assistance of the Upper and First-tier Tribunals Immigration and Asylum Chambers.

${ }^{6}$ With the exception of the three judges where the researcher was requested to take hand-written notes.

${ }^{7}$ Everyone liable to removal is on 'immigration bail'.

${ }^{8}$ In 2015, the Immigration Minister stated that of a reporting population of around 60,000 , around $95 \%$ of people comply with reporting restrictions on a week by week basis (APPG 2015: 25). A later Inspection found that of a reporting population of around 75,000 in December 2016, 91\% complied with their reporting restrictions (Bolt 2017). Many failures are isolated occurrences, e.g. owing to ill-health. Past evaluations focusing on specific groups of people released from detention have reported compliance rates of $90 \%$ or more (BID 2012, Ohtani and Phelps 2016). In the US, ICE's alternative to detention Intensive Supervision Appearance Program ensured $95 \%$ of participants appeared at scheduled removal hearings, and that only 5\% absconded and 4\% were arrested by another law enforcement agency (Koulish 2016a). Edwards (2011) concluded from a global study of alternatives to detention that in general less than $10 \%$ of people disappear if released to proper supervision and facilities.

${ }^{9}$ As distinct from removal, as it occurs on the grounds that their presence is not conducive to the public good (unless they fall within certain exceptions, for example that it would breach their Convention rights or UK obligations under the Refugee Convention categories) (UK Borders Act 2007).

${ }^{10}$ In a recent detention centre inspection, 60 people were considered at risk of self-harm over the previous six months; half of sufficiently high risk that they were under constant staff supervision, but there were no rule 35 reports on suicidal ideation (Bhui 2018).

${ }^{11}$ Only $2 \%$ of Rule 35 reports submitted for Medical Justice clients were assessed as Level 3, despite the fact that the reports often referred to significant symptoms including self-harm and PTSD (Medical Justice 2018, Mar-Oct 2017)
} 